\title{
Peningkatan Aktivitas Dan Hasil Belajar Siswa Pada Pembelajaran Matematika Realistik Di Kelas V SDN 8 Suwawa
}

\author{
Fatmah Akase \\ Guru Kelas V SDN 8 Suwawa \\ fatmah@gmail.com
}

\begin{abstract}
Received: 04 March 2021; Revised: 26 April 2021; Accepted: 28 July 2021
DOI: http://dx.doi.org/10.37905/aksara.7.3.1223-1230.2021
\end{abstract}

\begin{abstract}
Abstrak
Hasil belajar siswa kelas V mata pelajaran matematika tahun pelajaran 2019/2020 masih rendah. Hal ini terjadi karena penyampaian materi pelajaran oleh guru didominasi dengan penggunaan metode ceramah dan kurang mengaitkan materi pelajaran dengan dunia nyata, sehingga siswa kurang aktif dalam pembelajaran. Untuk mencapai hasil yang optimal, guru perlu menggunakan pendekatan pembelajaran yang dapat membantu siswa mengaitkan materi pelajaran dengan kehidupan sehari-hari siswa, sehingga pembelajaran menjadi lebih bermakna. Pendekatan tersebut yaitu Pembelajaran Matematika Realistik. Tujuan penelitian ini yaitu untuk meningkatkan aktivitas dan hasil belajar siswa kelas V serta performansi guru melalui Pembelajaran Matematika Realistik di SDN 8 Suwawa. Penelitian ini menggunakan desain penelitian tindakan kelas yang dilakukan dalam dua siklus. Setiap siklusnya terdiri dari empat tahap, yaitu perencanaan, tindakan, observasi, dan refleksi. Subjek penelitian ini yaitu siswa kelas V SDN 8 Suwawa tahun pelajaran 2020/2021 sejumlah 38 siswa. Teknik pengumpulan data dilakukan melalui tes (tes formatif) dan non tes (observasi dan dokumentasi). Indikator keberhasilan pada penelitian ini yaitu nilai rata-rata kelas $\geq 65$ dan persentase tuntas belajar klasikal $75 \%$, dan keterlibatan siswa dalam kegiatan pembelajaran $\geq 75 \%$, serta nilai performansi guru $\geq 75$. Hasil penelitian menunjukkan adanya peningkatan hasil belajar siswa, aktivitas belajar siswa, dan performansi guru dari siklus I ke siklus II. Pada siklus I, nilai rata-rata hasil belajar siswa mencapai 69,44 dan persentase tuntas belajar klasikal 69,44\%, sedangkan pada siklus II rata-rata hasil belajar menjadi 80,82 dan persentase tuntas belajar klasikal menjadi $86,11 \%$. Keterlibatan siswa dalam pembelajaran siklus I 71,76\% dan siklus II menjadi $78,40 \%$. Nilai performansi guru pada siklus I 83,01 dan meningkat pada siklus II menjadi 87,52.

Berdasarkan hasil tersebut, dapat disimpulkan bahwa Pembelajaran Matematika Realistik dapat meningkatkan aktivitas belajar siswa, hasil belajar siswa, dan performansi guru dalam pembelajaran matematika materi sifat-sifat bangun datar di kelas V SDN 8 Suwawa. Oleh karena itu, guru dapat menggunakan Pembelajaran Matematika Realistik sebagai alternatif pendekatan pembelajaran untuk meningkatkan kualitas pembelajaran di sekolah
\end{abstract}

Kata kunci : Aktivitas, Hasil Belajar, Matematika Realistik 


\section{PENDAHULUAN}

Menghindari kegiatan belajar yang bersifat monoton dan membosankan bagi peserta didik, maka metode pembelajaran sangat berperan. Syarat pemilihan metode harus disesuaikan dengan kondisi yang ada disuatu tempat agar tercipta suasana yang komunikatif, interaktif, dan kondusif dalam proses belajar mengajar.

Pembelajaran yang berkualitas adalah pembelajaran yang bisa membuat siswa lebih tertarik, merasa senang, dan termotivasi serta mampu menumbuhkan rasa ingin tahu terhadap apa yang sedang dipelajari. Para pendidik dituntut agar mampu menggunakan metode dalam proses pembelajaran yang tidak menutup kemungkinan bahwa metode tersebut sesuai dengan perkembangan dan tuntutan zaman. Tidak terlepas dari itu, tingkat keefektifan pembelajaran di Sekolah Dasar dipengaruhi oleh kemampuan guru menerapkan asas kekonkritan dalam pembelajaran yaitu salah satunya dengan penggunaan metode sehingga siswa mudah memahami pelajaran yang diajarkan.

Guru dan siswa bisa mempelajari keadaan sebenarnya di dalam kelas dengan mengharapkan para siswa pada metode inkuiri ilmiah yang aktual untuk dipelajari, diamati dalam hubungannya dalam proses mengajar. Cara ini lebih bermakna disebabkan para siswa dihadapkan dengan alat peraga secara benar dan nyata, lebih faktual dan kebenarannya lebih dapat dipertanggungjawabkan. Guru membawa alat peraga dalam rangka kegiatan belajar mengajar yang telah ditentukan 2 jam pelajaran (2x40 menit).

Namun pada kenyataannya, penggunaan alat peraga atau media pembelajaran oleh guru sekolah dasar masih belum optimal dan merata pada semua siswa, selain itu pembelajaran yang dilakukan guru masih mengacu pada pembelajaran konvensional. Menurut Stahl dalam Supinah (2008: 1), pembelajaran konvensional atau tradisional merupakan pembelajaran yang dilihat dari kegiatan siswa selama berlangsungnya pembelajaran bekerja untuk dirinya sendiri, mata ke papan tulis dan penuh perhatian, mendengarkan guru dengan saksama, dan belajar hanya dari guru atau bahan ajar, bekerja sendiri, diam adalah emas, serta hanya guru yang membuat keputusan dan siswa pasif. Pembelajaran tersebut menggambarkan guru lebih berperan aktif dalam pembelajaran, sedangkan siswa pasif. Guru tidak melibatkan aktivitas siswa selama proses pembelajaran, akibatnya matematika dianggap sebagai salah satu mata pelajaran di SD yang sulit dan capaian hasil belajar siswa kurang maksimal, termasuk materi sifat-sifat bangun datar

Berdasarkan refleksi guru kelas V di SDN 8 Suwawa, guru lebih sering menggunakan metode ceramah dan pemberian tugas. Guru belum menggunakan pendekatan, metode, maupun model pembelajaran yang inovatif dan realistik, serta dalam penggunaan alat peraga dan media pembelajaran belum merata pada semua siswa. Hal tersebut menyebabkan siswa kurang antusias pada pembelajaran matematika karena mereka hanya sebagai objek pembelajaran yang pasif dan hanya mengerjakan tugas yang diberi oleh guru.

Kurang optimalnya pembelajaran matematika di SDN 8 Suwawa dapat dilihat dari data pencapaian hasil belajar mata pelajaran matematika pada siswa kelas V semester II tahun pelajaran 2020/2021, yang secara rata-rata menunjukkan hasil di bawah kriteria ketuntasan minimal (KKM) yang ditetapkan sekolah yaitu 60, dari 41 siswa hanya 28 siswa yang tuntas dan 13 siwa yang tidak tuntas. Data hasil belajar ditunjukkan dengan nilai terendah 40 dan nilai tertinggi 80 dengan rata-rata kelas 58,78 dan persentase 
ketuntasan secara klasikal sebesar 68,29\%. Dengan melihat data hasil belajar dan pelaksanaan pembelajaran tersebut perlu sekali diadakan peningkatan aktivitas belajar agar siswa terlibat aktif dalam pembelajaran sehingga dapat meningkatkan pemahaman siswa terhadap materi pelajaran dan hasil belajar agar siswa kelas V sekolah dasar lebih menguasai pembelajaran geometri sebagai dasar untuk pembelajaran di kelas dan jenjang yang lebih tinggi, serta bekal dalam kehidupan sehari-hari.

Salah satu upaya yang dapat digunakan sebagai alternatif untuk meningkatkan aktivitas dan hasil belajar matematika yaitu dengan menggunakan Pembelajaran Matematika Realistik (PMR). PMR adalah salah satu pendekatan belajar matematika yang dikembangkan untuk mendekatkan matematika kepada siswa. Masalah-masalah nyata dari kehidupan sehari-hari digunakan sebagai titik awal pembelajaran matematika untuk menunjukkan bahwa matematika sebenarnya dekat dengan kehidupan sehari-hari.

\section{METODE PENELITIAN}

Penelitian Tindakan Kelas (PTK) merupakan suatu pencermatan terhadap kegiatan belajar berupa sebuah tindakan, yang sengaja dimunculkan dan terjadi dalam sebuah kelas secara bersama (Arikunto, Suhardjono, dan Supardi 2008: 3). Dalam pelaksanaan PTK minimal terdiri dari 2 siklus dimana pada masing-masing siklus terdapat 4 tahap/langkah penting, yaitu perencanaan, pelaksanaan tindakan, observasi, dan refleksi. Keempatnya harus terencana sebaik mungkin agar pelaksanaan penelitian dapat terlaksana dan mendapat hasil yang sesuai dengan keinginan peneliti.

Penelitian ini akan dilaksanakan di Sekolah Dasar Negeri 8 Suwawa Kecamatan Suwawa Kabupaten Bone Bolango dengan subjek penelitian adalah siswa kelas V tahun ajaran 2020/2021 dengan jumlah siswa 36 siswa yang terdiri dari 18 siswa laki-laki dan 18 siswa perempuan. Penelitian tindakan kelas ini dilaksanakan di SDN 8 Suwawa, Desa Tingkohubu Kecamatan Suwawa Kabupaten Bone Bolango, dengan lama waktu penelitian selama 6 bulan yaitu dari bulan Januari sampai Juni 2021

Jenis data dalam penelitian ini terdiri dari data kuantitatif dan kuantitatif. Data kuantitatif dalam penelitian ini berupa hasil belajar siswa pada materi sifat-sifat bangun datar yaitu nilai tes formatif siswa pada siklus I dan siklus II. ata kualitatif dalam penelitian ini berupa hasil pengamatan terhadap aktivitas belajar siswa dan performansi guru dengan menggunakan lembar pengamatan pada siklus I dan siklus II.

Teknik Pengumpul Data berdasarkan jenis data yang dikumpulkan, maka teknik pengumpulan data yang akan digunakan adalah sebagai berikut: (1) Teknik observasi langsung. Menurut Sudjana (2009:85) Observasi langsung adalah pengamatan yang dilakukan terhadap gejala atau proses yang terjadi dalam situasi yang sebenarnya dan langsung diamati oleh pengamat. Observasi tindakan ini dilakukan secara partisipasif yang dilakukan oleh penelitidan Observer sebagai kolaborator. (2) Teknik pengukuran.

\section{PEMBAHASAN}

Hasil penelitian yang guru lakukan dijadikan sebagai bahan pembahasan dalam skripsi. Hasil penelitian yang diperoleh meliputi hasil belajar, aktivitas siswa dan performansi guru yang dilakukan dalam dua siklus yaitu siklus I dan siklus II. Pembahasan dalam penelitian ini meliputi pemaknaan temuan penelitian dan implikasi hasil penelitian 
Berdasarkan penelitian yang telah dilakukan, siswa kelas V SDN 8 Suwawa sudah tidak merasa kesulitan mempelajari materi sifat-sifat bangun datar, hal ini ditandai dengan adanya antusiasme siswa selama pembelajaran berlangsung dan rata-rata hasil belajar yang dicapai siswa setelah diterapkannya Pembelajaran Matematika Realistik. Materi sifat-sifat bangun datar dapat dijumpai dalam kehidupan nyata sehari-hari, dengan menggunakan Pembelajaran Matematika Realistik dapat membantu siswa memahami materi matematika yang abstrak dengan kemampuan berpikir siswa yang konkret.

Penggunaan Pembelajaran Matematika Realistik ternyata dapat meningkatkan hasil belajar siswa pada materi sifat-sifat bangun datar. Terbukti dengan adanya peningkatan hasil belajar siswa dari siklus I ke siklus II. Pada siklus I nilai rata-rata hasil belajar siswa mencapai 69,44 dan ketuntasan belajar sebesar 69,44\%, sedangkan pada siklus II nilai rata-rata hasil belajar meningkat menjadi 80,30 dan ketuntasan belajar siswa mencapai 86,11\%. Peningkatan hasil belajar tersebut memiliki makna bahwa Pembelajaran Matematika Realistik efektif untuk pembelajaran matematika, karena pada Pembelajaran Matematika Realistik memberikan pengalaman belajar kepada siswa berupa pengalaman pada proses belajar melalui kegiatan membuat atau mengembangkan model dari permasalahan yang diajukan guru untuk memecahkan masalah. Proses belajar yang dialami siswa sesuai dengan pendapat Gagne dalam Anni dkk (2006: 4) bahwa belajar adalah suatu proses dimana suatu organisma berubah perilakunya akibat dari pengalaman.

Proses belajar yang dilakukan siswa mengakibatkan adanya perubahan perilaku. Perubahan perilaku yang dialami siswa sebagai hasil belajar ditandai dengan pemahaman siswa terhadap materi sifat-sifat bangun datar menjadi lebih baik. Perubahan perilaku yang diperoleh siswa sebagai hasil belajar sesuai dengan pendapat Hamalik (2008: 30) bahwa hasil belajar adalah terjadinya perubahan tingkah laku ketika seseorang telah belajar, misalnya dari tidak tahu menjadi tahu, dan dari tidak mengerti menjadi mengerti. Melalui Pembelajaran Matematika Realistik siswa lebih memahami materi sifat-sifat bangun datar, karena siswa mengalami proses membangun sendiri konsep mengenai sifatsifat bangun datar dengan memanipulasi alat peraga melalui permasalahan realistik yang diajukan oleh guru sehingga pembelajaran menjadi lebih bermakna serta motivasi siswa dalam belajar matematika menjadi lebih baik.

Aktivitas belajar siswa dalam pelaksanaan pembelajaran dengan menggunakan Pembelajaran Matematika Realistik juga mengalami peningkatan yang lebih baik dari siklus I ke siklus II. Persentase hasil aktivitas siswa pada siklus I sebesar 71,28\% meningkat pada siklus II menjadi 78,40\%. Peningkatan hasil aktivitas belajar tersebut memiliki makna bahwa Pembelajaran Matematika Realistik dapat mendorong aktivitas siswa selama pembelajaran berlangsung. Selama proses pembelajaran siswa diberi kebebasan untuk mengembangkan strategi pemecahan masalah dengan bantuan alat peraga untuk mengkonstruksi pengetahuan matematika dari matematika tingkat konkret menuju matematika tingkat abstrak.

Adanya aktivitas siswa dalam pembelajaran dapat meningkatkan pemahamannya terhadap materi dan menjadi lebih ingat karena ia mengalami sendiri proses belajarnya. Hal ini sesuai dengan pendapat Slameto (2010: 36), bahwa penerimaan pelajaran jika dengan aktivitas siswa sendiri, kesan itu tidak akan berlalu begitu saja, tetapi dipikirkan, diolah kemudian dikeluarkan lagi dalam bentuk yang berbeda. Selama pembelajaran guru tidak langsung mengawali pembelajaran dengan matematika formal tetapi mengajukan 
permasalahan yang harus dipecahkan oleh siswa dan guru telah menempatkan dirinya sebagai fasilitator dan pembimbing.

Hasil peneltian yang dilakukan guru dengan menggunakan Pembelajaran matematika Realistik pada materi sifat-sifat bangun datar di kelas V SDN 8 Suwawa adalah meningkatnya hasil belajar, aktivitas siswa, dan performansi guru. Hasil belajar, aktivitas siswa, dan performansi guru menggunakan Pembelajaran Matematika Realistik dapat meningkat apabila memperhatikan karakteristik siswa, karakteristik materi pelajaran, sarana dan prasarana, alokasi waktu pembelajaran, dan kondisi kelas.

Pembelajaran Matematika Realistik dapat meningkatkan hasil belajar siswa pada pelajaran matematika, apabila memperhatikan karakteristik materi pembelajaran. Jika guru akan menggunakan Pembelajaran Matematika Realistik maka harus memilih materi pelajaran yang dapat menyangkut kehidupan seharihari sehingga guru dapat mengaitkan antara kehidupan sehari-hari siswa dengan materi yang diajarkan. Materi sifat-sifat bangun datar dapat diterapkan dengan menggunakan pembelajaran matematika realistik, karena dalam kehidupan seharihari siswa selalu menjumpai benda-benda yang bentuk permukaannya menyerupai bangun datar tertentu. Guru dapat menggunakan konteks pada materi sifat-sifat bangun datar, dimana pada awal pembelajaran guru menggunakan konteks tersebut dijadikan sebagai masalah dari dunia nyata yang dapat dibayangkan oleh siswa. Masalah yang diajukan kepada siswa berupa soal yang harus dipecahkan dengan menggunakan alat peraga yang disediakan.

Pembelajaran Matematika Realistik dapat meningkatkan hasil belajar, apabila memperhatikan karakteristik siswa. Jika guru akan menggunakan Pembelajaran Matematika Realistik, maka guru harus memperhatikan karakteristik siswa. Karakteristik siswa kelas $\mathrm{V}$ yaitu senang dan sudah dapat menggunakan alat-alat atau benda-benda kecil dan memiliki rasa ingin tahu yang tinggi, lebih kritis, dan memiliki percaya diri yang berlebihan, hal tersebut sejalan dengan pembelajaran matematika realistik dimana dalam menyelesaikan masalah yang diajukan perlu adanya media ataupun model sebagai alat-alat atau benda kecil yang digunakan untuk menyatakan suatu hubungan dengan suatu formula (rumus), membuktikan keteraturan, membuat berbagai model, merumuskan konsep baru, melakukan generalisasi, dan sebagainya.

Aktivitas siswa dapat meningkat dengan menggunakan Pembelajaran Matematika Realistik. Jika guru akan menggunakan Pembelajaran Matematika Realistik, maka guru harus memberikan bimbingan, motivasi dan penguatan kepada siswa agar siswa lebih bersemangat dan aktif mengikuti pembelajaran matematika.

Dalam pelaksanaan Pembelajaran Matematika Realistik diperlukan banyak waktu pada kegiatan matematisasi horisontal maupun matematisasi vertikal untuk memecahkan masalah. Oleh karena itu, Pembelajaran Matematika Realistik banyak menyita waktu dalam proses matematisasi horisontal maupun matematisasi vertikal. Jika guru akan menggunakan Pembelajaran Matematika Realistik, maka harus memperhatikan alokasi waktu pembelajaran sesuai dengan permasalah yang diajukan oleh guru. Alokasi waktu yang digunakan guru dalam Pembelajaran Matematika Realistik pada materi sifat-sifat bangun datar adalah $2 \mathrm{JP}$, alokasi waktu tersebut harus digunakan sebaik mungkin agar proses belajar iswa dapat bermakna. Guru dapat mensiasati agar pembelajaran matematika realistik yang dilakukan tidak melebihi alokasi waktu yang telah ditetapkan dengan cara membagi siswa menjadi beberapa kelompok untuk memecahkan masalah yang diajukan, menggunakan media LCD atau kartu masalah untuk menyampaikan 
masalah kepada siswa, dan membimbing siswa dalam melakukan kegiatan yang interaktif.

Pembelajaran Matematika Realistik dapat meningkatkan performansi guru, apabila guru memperhatikan kondisi kelas. Jika guru akan menggunakan Pembelajaran Realistik, maka guru harus memperhatikan kondisi kelas agar pembelajaran yang dilakukan dapat berjalan lancar dan efektif. Guru harus dapat memperhatikan bagaimana kondisi siswa saat mengikuti pembelajaran, guru harus mengerti kapan siswa merasa sangat bersemangat dan kapan siswa merasa jenuh. Misalnya apabila siswa merasa jenuh maka guru dapat mengajak siswa untuk bernyanyi agar pikirannya rileks kembali, selain itu guru juga harus dapat membimbing siswa untuk dapat menyelesaikan masalah yang diajukan. Penjabaran di atas menunjukan bahwa dalam menggunakan Pembelajaran Matematika Realistik guru tidak hanya harus mengerti tentang pengertian Pembelajaran Matematika Realistik, bagaimana langkah-langkahnya, bagaimana karakteristiknya, tetapi selain itu guru juga harus dapat menyesuaikan antara karaktersitik siswa, karakteristik materi pelajaran, sarana dan prasarana, alokasi waktu pembelajaran, dan kondisi kelas untuk mendukung efektifnya pelaksanaan pembelajaran matematika dengan menggunakan Pembelajaran Matematika Realistik

\section{PENUTUP}

Berdasarkan hasil penelitian tindakan kelas yang dilaksanakan pada siklus I dan siklus II dengan menerapkan Pembelajaran Matematika Realistik pada siswa kelas V di SDN 8 Suwawa Kecamatan Suwawa Kabupaten Bone Bolango, menunjukkan adanya peningkatan aktivitas siswa, hasil belajar, dan performansi guru di kelas V pada materi sifat-sifat bangun datar. Adapun kesimpulan dari penelitian tersebut sebagai berikut:

Pembelajaran Matematika Realistik memberikan pengalaman belajar kepada siswa melalui pemecahan masalah kontekstual. Proses pemecahan masalah dilakukan secara kelompok mendorong aktivitas siswa menjadi aktif bertanya, kerjasama siswa dalam membuat atau mengembangkan model pemecahan menjadi lebih baik, siswa berani mempresentasikan hasil kerja, siswa berani mengemukakan pendapat, dan tekun dalam mengerjakan tugas yang diberi oleh guru. Peningkatan aktivitas siswa dalam pembelajaran dengan menggunakan pendekatan PMR pada siklus I mencapai 71,28\% dan siklus II mencapai 78,40\%.

Pembelajaran Matematika Realistik mendorong aktivitas siswa dalampemecahan masalah. Saat melakukan aktivitas pemecahan masalah, siswa diberi kesempatan mengkonstruksi pengetahuannya mengenai sifat-sifat bangun datar dengan strategi pemecahan masalah. Kegiatan pemecahan masalah tersebut membuat siswa lebih ingat terhadap materi yang diperolehnya, sehingga hasil belajar siswa menjadi meningkat. Peningkatan hasil belajar siswa, setelah guru menerapkan pembelajaran Matematika Realistik dibuktikan dari hasil tes formatif pada siklus I dan siklus II, nilai rata-rata siswa pada siklus I yaitu 69,44 kemudian meningkat pada siklus II menjadi 80,30 dan ketuntasan belajar siswa pada siklus I sebesar $69,44 \%$ meningkat pada siklus II menjadi $86,11 \%$.

Pembelajaran Matematika Realistik mendorong guru untuk belajar tentang hal-hal yang perlu diperhatikan dalam menggunakan Pembelajaran Matematika Realistik seperti karakteristik materi pelajaran, karakteristik siswa, sarana dan prasarana, alokasi waktu, dan kondisi kelas. Guru juga berusaha memahami perannya dalam Pembelajaran 
Matematika Realistik, yaitu sebagai fasilitator dan motivator dalam pembelajaran matematika, sehingga menambah kreatifitas guru dalam pembelajaran matematika yang menyebabkan performansi guru menjadi meningkat. Peningkatan performansi guru dalam penerapan Pembelajaran Matematika Realistik dalam bentuk Rencana Pelaksanaan Pembelajaran (RPP) dan pelaksanaan pembelajaran. Perolehan nilai performansi guru pada siklus I adalah 83,01 dan mengalami peningkatan pada siklus II menjadi 87,52

\section{DAFTAR PUSTAKA}

Aisyah, Nyimas, dkk. 2007. Pengembangan Pembelajaran Matematika SD. Jakarta: DEPDIKNAS DIRJENDIKTI

Aqib, Zaenal. 2008. Penelitian Tindakan Kelas untuk Guru. Bandung: Yrama Widya.

Arikunto, Suharsimi, Suhardjono, dan Supardi. 2008. Penelitian Tindakan Kelas. Jakarta: Bumi Aksara.

Hernawan, Asep Herry, dkk. 2008. Pengembangan Kurikulum dan Pembelajaran. Jakarta: Universitas Terbuka. Heruman. 2012. Model Pembelajaran Matematika di Sekolah Dasar. Bandung: Remaja Rosdakarya

Ismail, M. Ilyas. (2009). Kinerja dan Kompetensi Guru Dalam Pembelajaran. Available athttp://ilyasismailputrabugis.blogspot.com/2009/11/kinerja-dankompetensiguru-dalam.html [diakses 08/03/12].

Poerwanti, Endang, dkk 2008. Asesmen Pembelajaran SD. Jakarta: Direktorat Jenderal Pendidikan Tinggi Departemen Pendidikan Nasional. Riduwan. 2010. Metode dan Teknik Menyusun Tesis. Bandung: Alfabeta.

Slameto. 2010. Belajar dan Faktor-Faktor yang Mempengaruhi. Jakarta: Rineka Cipta

Supinah dan Agus D.W. 2009. Strategi Pembelajaran Matematika Sekolah Dasar. Yogyakarta: PPPPTK Matematika. Supinah, dkk. 2008. Pembelajaran Matematika SD dengan Pendekatan Kontekstual dalam Melaksanakan KTSP. Yogyakarta: PPPPTK Matematika.

Wijaya, Ariyadi. 2012. Pendidikan Matematika Realistik Suatu Alternatif Pendekatan Pembelajaran Matematika. Yogyakarta: Graha Ilmu.

Y.D, Sumanto, dkk. 2008. Gemar Matematika 5: untuk kelas V SD/MI. Jakarta: Pusat Perbukuan Departemen Pendidikan Nasional 
AKSARA: Jurnal Ilmu Pendidikan Nonformal

P-ISSN 2407-8018 E-ISSN 2721-7310 DOI prefix $\underline{10.37905}$

Volume 07, (03) September 2021

http://ejurnal.pps.ung.ac.id/index.php/Aksara 